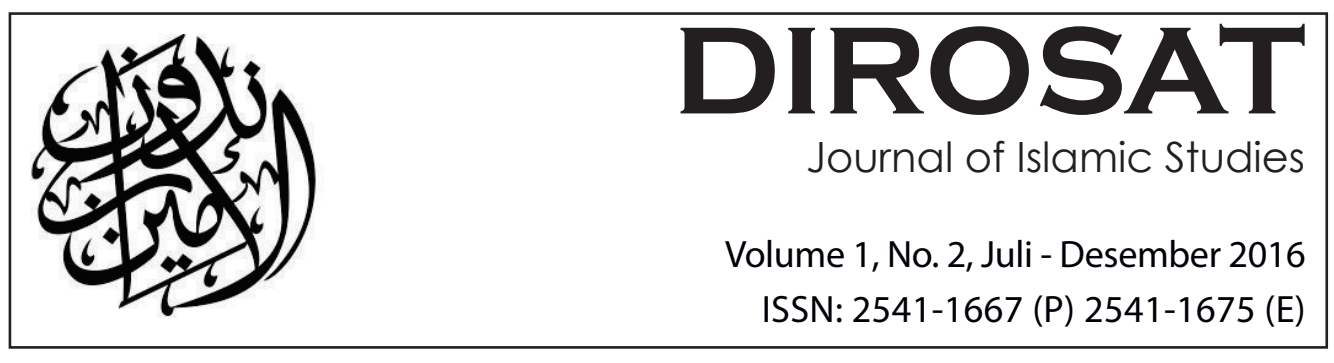

\title{
AHMAD DAHLAN DAN PESANTREN: GERAKAN PEMBAHARUAN PENDIDIKAN, DAKWAH, DAN PEMBERDAYAAN MASYARAKAT DI INDONESIA
}

Anwar Nuris el-Ali

Pemerhati Pendidikan Pesantren dari Indramayu

Abstrak: Gerakan pembaharuan Islam di Indonesia tidak bisa dilepaskan dari sosok Ahmad Dahlan melalui organisasi Muhammadiyah. Hal ini dapat ditelusuri melalui sejarah awal dan perkembangan Muhammadiyah yang ditunjukkan oleh ketokohan Ahmad Dahlan melalui ide pembaharuan atau gerakan tajdid. Artikel ini melihat ketokohan KH. Ahmad Dahlan dari sisi antropologis dan sosiologis. Pembacaan tersebut dimaksudkan untuk mengetahui peran sang tokoh dalam peta perkembangan masyarakatnya. Hal utama yang ingin dikaji dalam artikel ini adalah korelasi ketokohan KH. Ahmad Dahlan dan sistem pendidikan pesantren di Indonesia. Korelasi Muhammadiyah dan Pesantren dikaji dengan menggunakan pembahasan model simplifikasi kategoris pada tiga indikator fungsi dan peran Muhammadiyah, yaitu sebagai lembaga pendidikan dan pengembangan ajaran Islam, sebagai lembaga perjuangan dan dakwah Islamiyah, dan sebagai 
lembaga pemberdayaan dan pengabdian masyarakat. Dari ketiga kategori itulah dapat diketahui bahwa KH. Ahmad Dahlan adalah sosok yang mampu merespon tantangan terkininya secara cepat dan tepat melalui gerakan tajdid (pembaharuan) dalam bidang pendidikan, dakwah, dan pemberdayaan masyarakat Indonesia.

Kata Kunci: Ahmad Dahlan, Pembaharuan, Pendidikan, Dakwah, Pemberdayaan Masyarakat

Abstract: Islamic revitalization movement in Indonesia could not be separated from the figure of Ahmad Dahlan as a founder of Muhammadiyah. This can be traced through the early history and development of Muhammadiyah which is indicated by the lights of Ahmad Dahlan through Islamic revitalization movement. This article observes the personage of KH. Ahmad Dahlan from anthropological and sociological view. This observation is intended to find out the role of the person in the map of community development. The main aim of this article investigates correlation between the figure of KH. Ahmad Dahlan and educational system of the Islamic boarding school (pesantren) in Indonesia. The correlation of Muhammadiyah and Islamic boarding school is examined thorugh three categories as significant indicators to show the function and role of the Muhammadiyah. The three categories are: educational institution and the development of Islamic teachings, institution of struggle and Dakwah Islamiyah, and institution for community empowerment and public service. Of the three categories, this study found that $\mathrm{KH}$. Ahmad Dahlan is a figure who could respond to its latest challenges quickly and precisely through revitalization movement in the field of education, dakwah, and community empowerment in Indonesia.

Keywords: Ahmad Dahlan, revitalization, education, dakwah, community empowerment

\section{Pendahuluan}

- ema besar yang melingkupi kajian dalam tulisan ini adalah hubungan Muhammadiyah dan Pesantren. Muhammadiyah dipahami oleh banyak orang, setidaknya, sebagai organisasi sosial-keislaman yang didirikan KH. Ahmad Dahlan pada tanggal 18 November $1912 \mathrm{M}$ atau bertepatan dengan tanggal 8 Dzulhijjah 133 o H. Meski di belakangnya ada dukungan dari beberapa pelajar Budi Utomo seperti H. Sujak, H. Fachruddin, H. Tamim, H. Hisyam, 
H. Syarqawi, dan H. Abdul Gani; KH. Ahmad Dahlan tetap dianggap sebagai pendiri organisasi sosial keislaman bernama Muhammadiyah ini. Di samping gagasan untuk menciptakan tatanan masyarakat yang adil dan makmur sesuai dengan nafas Al-Qur'an dan al-Hadis, pendirian organisasi ini juga dilatari oleh ide dan gerakan pembaharuan yang terjadi di Timur Tengah.

Penelusuran basis sejarah awal dan perkembangan Muhammadiyah selanjutnya dapat diidentifikasi pada dua point: Pertama, sosok bernama KH. Ahmad Dahlan; dan Kedua, ide pembaharuan atau gerakan tajdid. Pembacaan diri pada sosok KH. Ahmad Dahlan adalah pembacaan antropologis dan sosiologis, bukan pembacaan psikologis dan intelektualis. Artinya, sosok KH. Ahmad Dahlan lebih dibaca sebagai makhluk sosial yang memiliki keterkaitan peran dalam peta perkembangan masyarakat daripada membaca sosok KH. Ahmad Dahlan sebagai pribadi dan pemikir. ${ }^{1}$ Di sisi lain Muhammadiyah diidentifikasi pada proses upaya realisasi ide-ide dan gerakan pembaharuan atas ajaran-ajaran Islam yang - menurutnya - seringkali terkontaminasi oleh pesanpesan konteks budaya, di satu sisi, dan atas kebijakan pemerintah kolonial Belanda yang cenderung menempatkan orang Islam dan sebagian besar masyarakat pribumi pada posisi sosial yang rendah. ${ }^{2}$ Di sini dapat disepakati bahwa Muhammadiyah didirikan sebagai salah satu model respon sosial.

Sedangkan Pesantren, lebih mudahnya, dilihat sebagai Indonesian Indeginous Culture dan Indonesian Indeginous System of Education. Dikatakan sebagai Indonesian Indeginous Culture karena dalam kenyataan kultural ada sejumlah elemen keseharian pesantren yang masih hidup hingga hari ini dan elemen ini menjadi lebih mudah dipahami bila dikaitkan dengan budaya pribumi pra-Islam ketimbang budaya Islam Timur Tengah. ${ }^{3}$ Disebut Indonesian Indeginous System of Education karena pola pengajaran semacam sorogan, wetonan

1 "Ahmad Dahlan bukan seorang penulis sebagaimana Muhammad Natsir. Oleh karena itu, gagasangagasan pemikirannya ia sampaikan secara lisan dan karya nyata. Untuk itu ia lebih dikenal sebagai pelaku dibanding sebagai pemikir". Lihat, Abuddin Nata, Tokoh-tokoh Pembaruan Islam di Indonesia, (Jakarta: Raja Grafindo Persada, 2005), 99.

2 Struktur yuridis formal masyarakat kolonial secara tegas membedakan kelompok masyarakat berdasarkan suku bangsa. Dalam stratifikasi masyarakat kolonial; penduduk pribumi menempati posisi yang paling rendah, sedangkan lapisan atas diduduki orang Eropa, kemudian orang Timur Asing, seperti: orang Cina, Jepang, Arab, dan India.

3 Tradisi "selamatan" boleh jadi adalah salah satu contoh aktual. 
dan bandungan di langgar atau di rumah kyai-nya sendiri juga lebih mudah dipahami jika dihubungkan dengan pola penyebaran agama Islam yang dilakukan oleh Syekh Maulana Malik Ibrahim (w. 1419) di Gapura Gresik. Menurut data sejarah yang terhimpun, Syekh Maulana Malik Ibrahim merupakan orang pertama yang memperkenalkan pola pengajaran dalam format pondok pesantren yakni ketika mendirikan pondok pesantren di desa Gapura, Gresik. Pengenalan pola pengajaran format pesantren ini kemudian dilanjutkan oleh Sunan Ampel dengan mendirikan Pondok Pesantren Ampel Denta di Surabaya, Sunan Giri di Giri Gresik, Sunan Bonang di Tuban, Sunan Drajad di Lamongan dan Raden Patah di Demak.

Perspektif kesejarahan perkembangan pesantren selanjutnya inilah, pada dasarnya, telah mengidentifikasi peran dan fungsi pada tiga poin yaitu: Pertama, pesantren sebagai lembaga pendidikan dan pengembangan ajaran Islam; Kedua, pesantren sebagai lembaga perjuangan dan dakwah Islamiyah; Ketiga, sebagai lembaga pemberdayaan dan pengabdian masyarakat. ${ }^{4}$

Sejak awal, hal utama yang ingin dijelaskan dalam tulisan ini adalah korelasi peran sosok KH. Ahmad Dahlan pada peran dan fungsi pesantren di Indonesia. Hal ini dilakukan demi kepentingan fokus analisa kajian semata, bukan atas dasar niatan enkripsi peta korelasi Muhammadiyah dan Pesantren. Karenanya, boleh jadi, tulisan ini hanyalah bertindak sebagai catatan pinggir dari sebuah desain korelasi Muhammadiyah dan Pesantren seutuhnya.

\section{Ahmad Dahlan: Kilasan Hidup Sang Pencerah}

Ahmad Dahlan lahir dengan nama kecil Muhammad Darwisy dalam sebuah keluarga didaktis yang terkenal alim dalam ilmu agama pada 1 Agustus 1868 di Kampung Kauman Jogjakarta. Dari ayah bernama K.H. Abu Bakar (imam dan khatib masjid besar Kraton Yogyakarta) dan ibu bernama Siti Aminah (putri K.H. Ibrahim, penghulu di Kraton Yogyakarta), Dahlan merupakan putra keempat dari tujuh bersaudara, yaitu Katib Harum, Mukhsin atau Nur, Haji Shaleh, Ahmad Dahlan, 'Abd Al-Rahim, Muhammad Pakin dan Basir. Dalam

4 Disamping 3 poin ini, secara ideologis pesantren diidentifikasi sebagai lembaga tafaqquh fiddin, yang mengemban misi meneruskan risalah Nabi Muhammad SAW. sekaligus melestarikan ajaran Islam yang berhaluan Ahl al-Sunnah wal al-Jamā'ah 'alā Țarīqah al-Madhāhib al-Arba'ah. Baca Mukernas V RMI (Rabithah al-Ma‘ahid al-Islamiyah) No. o3/Mukernas V/1996. 
silsilahnya, ia tercatat sebagai keturunan kedua belas dari Maulana Malik Ibrahim, salah seorang wali songo yang merupakan pelopor pertama dari penyebaran dan pengembangan dakwah Islam di Tanah Jawa. ${ }^{5}$

Perjalanan keilmuannya di tanah air tergolong panjang dan variatif: Belajar mengaji Al-Qur`an dan kitab-kitab agama lain kepada ayahnya, K.H. Abu Bakar; belajar fiqih pada KH. Muhammad Saleh; belajar nahwu pada KH. Muhsin; belajar ilmu falak pada KH. R. Dahlan; belajar hadis pada KH. Mahfuz dan Syekh Khayyat Sattokh; dan belajar qiraat pada Syekh Amin dan Syekh Sayyid Bakri. Setelah menimba ilmu pada sejumlah guru di Tanah Air, pada tahun $1883 \mathrm{M}$ hingga 1888 M, Muhammad Darwisy berangkat ke Mekkah untuk menuntut ilmu agama dan bahasa Arab. Di sinilah ia berinteraksi dengan pemikiran-pemikiran pembaru dunia Islam, seperti; Syekh Muhammad bin Abdil Wahhab, Syekh Jamalaluddin Al-Afghani, Syekh Muhammad Abduh, Syekh Muhammad Rasyid Ridha, dan Shaykh al-Islām Ibnu Taimiyah. Dan pada tahun 1902 M, setelah menunaikan ibadah haji, ia kembali memperdalam ilmu agamanya kepada sejumlah ulama di Makkah dan beberapa ulama asal Indonesia yang bermukin disana, seperti; Syekh Muhammad Khatib al-Minangkabawi, ${ }^{6}$ Kyai Nawawi alBantani, Kyai Mas Abdullah, dan Kyai Fakih Kembang. Setelah memperdalam ilmu agamanya di Mekkah untuk yang kedua kalinya, Dahlan kembali ke tanah air pada $1904 \mathrm{M}^{7}$

Kepergiannya ke Mekkah yang kedua kalinya itu semakin mempertinggi kemampuannya dalam ilmu agama dan semakin membuka wawasan KH. Ahmad Dahlan tentang universalitas Islam. K. R. Haiban Hadjid ${ }^{8}$ mengilustrasikan sosok KH.Ahmad Dahlan sebagai berikut: "Seumpama para ulama saya gambarkan sebagai tentara, dan kitab-kitab yang tersimpan dalam perpustakaan-perpustakaan, took-

5 Silsilah lengkapnya ialah Muhammad Darwisy bin KH Abu Bakar bin KH Muhammad Sulaiman bin Kyai Murtadla bin Kyai Ilyas bin Demang Djurung Djuru Kapindo bin Demang Djurung Djuru Sapisan bin Maulana Sulaiman Ki Ageng Gribig (Djatinom) bin Maulana Muhammad Fadlul'llah (Prapen) bin Maulana 'Ainul Yaqin bin Maulana Ishaq bin Maulana Malik Ibrahim. Lihat, http:// www.tokohindonesia.com/ensiklopedi/a/ahmad-dahlan/index.html.

6 Syekh Muhammad (Ahmad) Khatib Al-Minangkabawi juga merupakan salah seorang guru dari KH. Hasyim Asy'ari, pendiri NU. Lihat; http://id.wikipedia.org/wiki/Ahmad_Dahlan.

7 Drs. Margono Poespo Suwarno, Gerakan Islam Muhammadiyah. (Yogyakarta, Persatuan Baru, 2005), 13-24.

8 KRH. Hadjid adalah murid termuda KH. Ahmad Dahlan. 
toko kitab, saya gambarkan sebagai senjata-senjata yang tersimpan dalam gudang, maka K.H. Ahmad Dahlan seperti salah satunya tentara yang tahu mempergunakan bermacam-macam senjata menurut mestinya". Ia menambahkan ${ }^{9}$ bahwa kitab-kitab membentuk dan mengisi jiwa KH. Ahmad Dahlan adalah kitab-kitab Aqā’id yang beraliran Ahlus Sunnah wal Jama'ah; Kitab ilmu Fiqh dari Madzhab Shāfíiyyah; Kitabkitab ilmu Tasawuf karangan imam al-Ghazali; Tafsir Al-Manār karangan Rasyid Ridha; Majalah al-Manār dan Tafsir Juz 'Amma karangan Mohammad Abduh; Kitab al-'Urwat al-Wuthqā karangan Jamaluddin al-Afghani; Kitab Kanz al-'Ulūm karya Ibnu Bathuthah; Dā'irat al-Ma'ârif karangan Farid Wadji; Kitab-kitab bid'ah karangan Ibnu Taymiyah seperti Kitab al-Tawassul wa al-Wasīlah; Kitab al-Islām wa al-Nașrāniyyah karangan Mohammad Abduh; Kitab Ižhār al-Haqq karangan Rahmatullah al-Hindi; dan kitab-kitab hadis karangan ulama madzhab Hambali lainnya.

Munir Mulkhan ${ }^{10}$ menyimpulkan garis besar pokok pikiran Kyai Haji Ahmad Dahlan sebagai berikut: 1. Persatuan umat manusia adalah prinsip utama kebahagiaan dan merupakan induk segala ilmu yang harus dipimpin dengan metode al-Qur'an; 2. Perpecahan umat manusia disebabkan: (a) sempitnya wawasan pemikiran yang disebabkan rendahnya pengetahuan; (b) terjebak pada perdebatan lisan dan mengabaikan tindakan nyata; (c) ekslusifisme atau wawasan fanatisme golongan yang sempit; 3. Persatuan umat manusia akan diperoleh dengan jalan:(a) memahami kondisi obyektif umat; (b) bekerja atas kemampuan sendiri; (c) tidak tergesa menolak atau menerima sesuatu sebelum memahami; 4. Kebenaran diperoleh melalui: (a) bersikap terbuka terhadap penemuan baru; (b) berfikir kritis, luas dan dalam; 5. Penolakan kebenaran sebagai akibat: (a) kebodohan; (b) sikap ekslusif; (c) fanatisme pada tradisi dan kebiasaan; (d) takut kehilangan teman, harta dan kehormatan; 6. Keputusan yang benar adalah keputusan menurut akal-pikiran dengan hati yang yang suci; 7. Manusia wajib memajukan ilmu pengetahuan dan berbuat berdasarkan pengetahuan; 8. Akal sehat adalah jalan mencapai tujuan manusia dan pengetahuan adalah kebutuhan akal; 9. Pendidikan akal adalah kebutuhan pokok manusia lebih dari kebutuhan makan dan minum; 10. Ilmu Manțiq atau Logika (Filsafat) merupakan pendidikan tertinggi bagi akal; 11. Orang yang paling baik adalah orang menghidup-hidupkan perkataan orang

9 KRH. Haiban Hadjid, Pelajaran KH. Ahmad Dahlan; 7 Falsafah Ajaran dan 17 Kelompok Ayat AlQur'an.(Yogyakarta: LPI PPM, 2008), 29.

10 Abdul Munir Mulkhan, Masalah-Masalah Teologi dan Fiqih dalam Tarjih Muhammadiyah. (Yogyakarta: ROYKHAN, 2005). 
yang bijaksana dan ilmuwan; 12. Kebahagiaan dunia dan akhirat harus dicapai secara profesional (tidak serampangan); 13. Tidak benci kepada orang yang berbeda pendapat; 14. Orang yang cerdas adalah: (a) orang yang kreatif; (b) selalu berusaha mencari jalan keluar dari penderitaan, dan (c) selalu ingat kepada Allah.

Ahmad Dahlan menikahi lebih dari seorang istri. Istri pertamanya, yaitu Siti Walidah, masih sepupunya sendiri, anak Kyai Penghulu Haji Fadhil yang dikenal dengan Nyai Ahmad Dahlan, seorang Pahlawanan Nasional dan pendiri Aisyiyah. Dari perkawinannya dengan Siti Walidah, Ahmad Dahlan dikaruniai enam orang anak, yaitu Djohanah, Siradj Dahlan, Siti Busyro, Irfan Dahlan, Siti Aisyah, dan Siti Zaharah. Istri keduanya yaitu Nyai Abdullah, janda H. Abdullah. Dan beberapa istri beliau yang lain, yaitu Nyai Rum, adik Kyai Munawwir Krapyak; Nyai Yasin Pakualaman; dan Nyai Aisyah, adik adjengan penghulu Cianjur. Dari perkawinannya dengan Nyai Aisyah, beliau punya anak Dandanah."

KH. Ahmad Dahlan wafat di Yogyakarta pada tanggal 23 Februari tahun 1923 dan dimakamkan di Karangkajen, Yogyakarta.

\section{Ahmad Dahlan dan Pesantren}

Bahasan tentang korelasi Muhammadiyah dan Pesantren berikut dilakukan dengan menggunakan pembahasan model simplifikasi kategoris: Muhammadiyah menjadi peran KH. Ahmad Dahlan dan Pesantren menjadi 3 indikator fungsi dan peran yaitu sebagai lembaga pendidikan dan pengembangan ajaran Islam; sebagai lembaga perjuangan dan dakwah Islamiyah; dan sebagai lembaga pemberdayaan dan pengabdian masyarakat. Tentu saja, model simplifikasi kategoris ini dirumuskan demi kepentingan fokus kajian semata yang sengaja dijadikan kerangka paradigmatis agar pemetaan kajian korelasi secara jelas dapat dicapai.

\section{Ahmad Dahlan dalam Pendidikan dan Pengembangan Ajaran Islam.}

Gagasan-gagasan besar KH. Ahmad dahlan dalam dunia pendidikan ini dapat ditelisik pada pandangannya tentang pendidikan integralistik. Baginya,

\footnotetext{
11 Lihat: http://id.wikipedia.org/wiki/Ahmad_Dahlan dan http://www.tokohindonesia.com/ ensiklopedi/ a/ahmad-dahlan/index.html.
} 
pendidikan Islam hendaknya diarahkan pada usaha membentuk manusia muslim yang berbudi pekerti luhur, alim dalam agama, luas pandangan dan paham masalah ilmu keduniaan, serta bersedia berjuang untuk kemajuan masyarakatnya. Pandangan ini muncul sebagai anti-tesa dari tujuan pendidikan yang saling bertentangan pada saat itu, yakni pendidikan pesantren dan pendidikan sekolah model Belanda. Di satu sisi, pendidikan pesantren hanya bertujuan untuk menciptakan individu yang saleh dan mendalami ilmu agama. Sebaliknya, pendidikan sekolah model Belanda merupakan pendidikan sekular yang di dalamnya tidak diajarkan agama sama sekali. Akibat dualisme pendidikan tersebut, lahirlah dua kutub intelektual: lulusan pesantren yang menguasai agama tetapi tidak menguasai ilmu umum dan alumni sekolah Belanda yang menguasai ilmu umum tetapi tidak menguasai ilmu agama.

Demi tercapainya impian pendidikan integralistik ini, KH. Ahmad Dahlan kemudian berpendapat ${ }^{12}$ bahwa kurikulum atau materi pendidikan Islam hendaknya meliputi: 1. Pendidikan akhlaq, yaitu sebagai usaha menanamkan karakter manusia yang baik berdasarkan Al-Qur’an dan Sunnah; 2. Pendidikan individu, yaitu sebagai usaha untuk menumbuhkan kesadaran individu yang utuh lagi berkesinambungan antara perkembangan mental dan gagasan, antara keyakinan dan intelektual serta antara dunia dengan akhirat; dan 3. Pendidikan kemasyarakatan, yaitu sebagai usaha untuk menumbuhkan kesediaan dan keinginan hidup bermasyarakat.

Model penyampaian materi-materi pendidikan Islam di atas adalah model penyampaian kontekstual dan bukan tekstual, karena pelajaran agama tidak cukup hanya dihafalkan atau dipahami secara kognitif, tetapi harus diamalkan sesuai situasi dan kondisi. Corak kontekstual dalam metode pembelajaran yang dikembangkan K.H. Ahmad Dahlan adalah metode pembelajaran melalui proses penyadaran. Contoh klasik adalah ketika Beliau menjelaskan surat al-Ma'un kepada murid-muridnya secara berulang-ulang sampai santri itu menyadari bahwa surat itu menganjurkan supaya kita memperhatikan dan menolong fakir-miskin, dan harus mengamalkan isinya. Setelah santrisantri itu mengamalkan perintah itu baru diganti surat berikutnya. Corak

\footnotetext{
12 Samsul Nizar. Filsafat Pendidikan Islam; Pendidikan Historis Teoritis. (Jakarta: Ciputat Press, 2002), 107.
} 
pembelajaran model ini muncul sebagai akibat dari pemahaman KH. Ahmad Dahlan tentang klasifikasi pelajaran menjadi dua bagian yaitu (a) belajar ilmu, yakni pengetahuan atau teori; dan (b) belajar amal, yakni mengerjakan atau mempraktekkan. Menurutnya, ${ }^{13}$ semua pelajaran harus dengan cara sedikit demi sedikit, setingkat demi setingkat. Demikian pula dalam belajar amal, harus dengan cara bertingkat. Kalau setingkat saja belum dapat mengerjakan, tidak perlu ditambah.

Ijtihad pemikiran pendidikan Islam yang digagas K.H. Ahmad Dahlan melalui gagasan dan praktek pendidikan Islam-nya diterapkan di pondok Muhammadiyah. Ada empat pokok model pembaharuan pendidikan di Pondok Muhammadiyah antara lain: ${ }^{14}$

\begin{tabular}{|c|l|l|}
\hline No & \multicolumn{1}{|c|}{ Sistem Pendidikan Lama } & \multicolumn{1}{|c|}{ Pondok Muhammadiyah } \\
\hline 1 & $\begin{array}{l}\text { Sistem belajar mengajar Weton } \\
\text { dan Sorogan. }\end{array}$ & $\begin{array}{l}\text { Sistem klasikal dengan cara-cara } \\
\text { Barat. }\end{array}$ \\
\hline 2 & $\begin{array}{l}\text { Bahan pelajaran semata-mata } \\
\text { agama, kitab-kitab karangan } \\
\text { ulama pembaharuan tidak } \\
\text { dipergunakan. }\end{array}$ & $\begin{array}{l}\text { Bahan pelajaran tetap, ditambah } \\
\text { ilmu pengetahuan umum. Kitab- } \\
\text { kitab agama dipergunakan } \\
\text { secara luas, baik klasik maupun } \\
\text { kontemporer. }\end{array}$ \\
\hline 3 & $\begin{array}{l}\text { Belum ada Rencana } \\
\text { Pembelajaran yang teratur dan } \\
\text { integral. }\end{array}$ & $\begin{array}{l}\text { Sudah diatur dengan Rencana } \\
\text { Pembelajaran. }\end{array}$ \\
\hline
\end{tabular}

13 K.R. Haiban Hadjid, Pelajaran KH. Ahmad Dahlan; 7 Falsafah Ajaran dan 17 Kelompok Ayat AlQur'an. (Yogyakarta: LPI PPM, 2008), 21.

14 Amir Hamzah Wirjosukarto, Pembaharuan Pendidikan dan Pengajaran Islam (Jember, Mutiara Offset, 1985), 98-108.

15 Pelajaran agama meliputi pelajaran Qur'an dan hadis, kitab-kitab fiqh (mazhab Syafi'i), ilmu tasawuf (al-Ghazali), Ilmu kalam (ulama-ulama Ahlus Sunnah) ditambah dengan kitab Risālah al-Tauhīd (Muhammad Abduh), kitab Tafsīr al-Jalālayn dan al-Manār. Sedangkan pengetahuan umumnya meliputi: ilmu sejarah, berhitung, menggambar bahasa Melayu, bahasa Belanda dan Inggris. Lihat: Amir Hamzah Wirjosukarto, Pembaharuan Pendidikan, h. 122-123. 


\begin{tabular}{|c|l|l|}
\hline No & \multicolumn{1}{|c|}{ Sistem Pendidikan Lama } & \multicolumn{1}{c|}{ Pondok Muhammadiyah } \\
\hline \multirow{2}{*}{4} & $\begin{array}{l}\text { Hubungan guru dan murid lebih } \\
\text { bersifat otoriter dan kurang } \\
\text { demokratis. }\end{array}$ & $\begin{array}{l}\text { Diusahakan suasana hubungan } \\
\text { guru dan murid lebih akrab bebas } \\
\text { dan demokratis. }\end{array}$ \\
\hline
\end{tabular}

\section{Ahmad Dahlan dalam Perjuangan dan Dakwah Islamiyah.}

Tidak dapat dipungkiri bahwa Muhammadiyah lahir dari 'pembacaan' kreatif KH. Ahmad Dahlan atas pesan suci Al-Qur'an. Dalam memahami Islam, Muhammadiyah tidak melihat dari sudut formalistis melainkan Islam dipahami sebagai suatu nilai yang Integral dan tidak mempersempitnya. Hal ini terlihat pada cara Muhammadiyah (baca: KH. Ahmad Dahlan) menempatkan akal sebagai 'pisau' bedah ajaran-ajaran Islam untuk diaplikasikan dalam dataran praksis. Pesan pencerahan akal melalui filsafat dan logika oleh KH. Ahmad Dahlan dapat dicermati pada naskah pidato terakhirnya yang berjudul Tali Pengikat yang, setidaknya, menyiratkan tiga kalimat kunci yaitu: (1) Pengetahuan tertinggi adalah pengetahuan tentang kesatuan hidup yang dapat dicapai dengan sikap kritis dan terbuka dengan mempergunakan akal sehat dan istiqamah terhadap kebenaran akali dengan didasari hati yang suci; (2) Akal adalah kebutuhan dasar hidup manusia; (3) Ilmu mantiq atau logika adalah pendidikan tertinggi bagi akal manusia yang hanya akan dicapai hanya jika manusia menyerah kepada petunjuk Allah SWT.

Pesan rasionalitas KH. Ahmad Dahlan kemudian menjadi tradisi di setiap gerakan Muhammadiyah dalam upaya pemurnian dan pembaharuan (tajdid). Pesan pencerahan akal ini secara eksplisit menyerukan ijtihad dan menolak taqlìd. Dengan upaya pencerahan akal ini, ummat Islam dapat menyelesaikan permasalahanpermasalahan umat kekinian sehingga pada akhirnya Islam menjadi lebih membumi (down to earth). Jelasnya, Muhammadiyah menganggap bahwa tajdid merupakan salah satu watak dari Ajaran Islam.

Untuk itu, konteks keber-Islaman orang Muhammadiyah tidak hanya berkutat pada ranah ibadah mahdah, namun merambah pada ranah ghairu mahdah yakni pada upaya bagaimana Islam ini dapat membentuk masyarakat adil, makmur dan masyarakat Islam yang sebenar-benarnya. Masyarakat Islam yang sebenarnya bukanlah ditunjukkan oleh ber-islamnya seluruh rakyat Indonesia atau umat manusia, melainkan ditunjukkan oleh ajaran Islam yang membumi sebagai rahmmah li al- 
àlamin. Dalam pandangan Muhammadiyah, kesalehan dalam ranah ritual dan sosial bukanlah hal yang perlu untuk dipilih mana yang lebih tinggi, namun dua hal tersebut dipandang sebagai dua sisi sebuah kesalehan yang harus berjalin-berkelindan.

Prinsip-prinsip dasar inilah yang menjadi framework perjuangan dan dakwah Islamiyah KH. Ahmad Dahlan. Sedangkan bentuk-bentuk perjuangan dan dakwah Islamiyah KH. Ahmad Dahlan dapat dilihat berikut ini:

1. Melakukan purifikasi ajaran Islam dari khurafat tahayul dan bid'ah yang telah bercampur dalam akidah dan ibadah umat Islam, dan mengajak umat Islam untuk keluar dari jaring pemikiran tradisional melalui reinterpretasi terhadap doktrin Islam dalam rumusan dan penjelasan yang dapat diterima oleh rasio. ${ }^{16}$

2. Usaha dan jasanya mengubah dan membetulkan arah kiblat yang tidak tepat menurut mestinya. Umumnya masjid-masjid dan langgar-langgar di Yogyakarta menghadap Timur dan orang-orang shalat mengahadap ke arah Barat lurus. Padahal kiblat yang sebenarnya menuju Ka'bah dari tanah Jawa haruslah miring kearah Utara \pm 24 derajat dari sebelah Barat. Berdasarkan ilmu pengetahuan tentang ilmu falak itu, orang tidak boleh menghadap kiblat menuju Barat lurus, melainkan harus miring ke Utara + 24 derajat. Oleh sebab itu, K.H. Ahmad Dahlan mengubah bangunan pesantrennya sendiri supaya menuju ke arah kiblat yang benar. Perubahan yang diadakan oleh K.H. Ahmad Dahlan itu mendapat tantangan keras dari pembesar-pembesar masjid dan kekuasaan kerajaan.

3. Berdasarkan perhitungan astronominya, K.H. Ahmad Dahlan menyatakan bahwa hari raya Idul Fitri yang bersamaan dengan hari ulang tahun Sultan, harus dirayakan sehari lebih awal dari yang diputuskan para ulama "mapan". Dan melaksanakan shalat Idul Fitri di lapangan. Sultan menerima pendapat K.H. Ahmad Dahlan namun karena ini pula beliau kehilangan lebih banyak lagi simpati dari kalangan ulama "mapan". ${ }^{17}$

16 Samsul Nizar. Filsafat Pendidikan Islam; Pendidikan Historis Teoritis. (Jakarta: Ciputat Press, 2002), 103-104.

17 A. Mukti Ali, The Muhammadiyah Movement: Allah SWT Bibliographical Introcution", Tesis Master pada Institute of Islamic Studies (Mc Gill Univercity, Montreal, 1957), 32. 
4. Mengajarkan dan menyiarkan agama Islam dengan popular, bukan saja di pesantren, melainkan ia pergi ke tempat-tempat lain dan mendatangi berbagai golongan. Bahkan dapat dikatakan bahwa K.H. Ahmad Dahlan adalah bapak Muballig Islam di Jawa Tengah, sebagaimana syekh M. Jamil Jambek sebagai bapak Muballigh di Sumatra Tengah. ${ }^{18}$

Bertolak dari gerakan-gerakan yang dilakukan oleh tokoh sentralnya KH. Ahmad Dahlan inilah, Munir Mulkhan berpendapat ${ }^{19}$ bahwa secara prinsip dalam gerakannya Muhammadiyah dapat diidentifikasi ke dalam 5 kategori gerakan yaitu (a) Gerakan Islam; (b) Gerakan Sosial; (c) Gerakan Dakwah; (d) Gerakan Tajdid; (e) Gerakan Ilmu.

\section{Ahmad Dahlan dalam Pemberdayaan dan Pengabdian Masyarakat.}

Sejak awal, perjalanan historis penyebaran agama Islam di Indonesia melalui proses akulturasi dan sinkretisme budaya. Model penyebaran Islam dengan model ini, di satu sisi telah berhasil meningkatkan kuantitas umat Islam, menyisakan permasalahan kualitas umat Islam akan orisinalitas dan kemurnian ajaran Islam. Menurut catatan T.S. Raffles tentang Islam di Jawa pada awal abad XIX, banyak orang Jawa yang berpengetahuan cukup tentang Islam dan berprilaku sesuai dengan ajaran Islam hanya beberapa orang saja. K.H. Ahmad Rifa'i, salah seorang ulama di Jawa yang sangat disegani oleh pemerintah kolonial pada pertengahan abad XIX, juga menyatakan bahwa pengamalan agama Islam orang Jawa banyak menyimpang dari akidah Islam dan harus diluruskan. Pemahaman dan pengamalan ajaran Islam yang sinkretik dan sikap taqlid terhadap ulama adalah salah satu contoh nyata kondisi masyarakat Muslim Indonesia pada akhir abad XIX. Di Pulau Jawa, misalnya, persoalan kemurnian ajaran Islam ini sangat terasa karena unsur-unsur lokal sangat berpengaruh dalam proses sosialisasi ajaran di dalam masyarakat seperti yang terlihat pada: sekaten, kenduri, tahlilan, dan wayang.

Dinamika internal masyarakat Islam Indonesia semacam ini juga diperparah oleh perluasan kekuasaan pemerintah kolonial Belanda. Islam sejak

18 Hamdani Ihsan dan Fuad Ihsan, Filsafat Pendidikan Islam. (Bandung: Pustaka Setia, 2001), 276.

19 Abdul Munir Mulkhan, Masalah-Masalah Teologi dan Fiqih dalam Tarjih Muhammadiyah. (Yogyakarta: ROYKHAN, 2005) 
awal muncul sebagai kekuatan di balik perlawanan terhadap kolonialisme, baik dalam pengertian idiologis maupun peran langsung para ulama dan umat Islam secara keseluruhan. Akibatnya, pemerintah kolonial cenderung melihat Islam sebagai ancaman langsung dari eksistensi kekuasaan kolonial ini. Setiap aktifitas yang berhubungan dengan Islam selalu dicurigai dan dianggap sebagai langkah untuk melawan penguasa. Oleh sebab itu, berdasarkan konsep yang dikembangkan oleh C. Snouck Hurgronje pada akhir abad XIX, pemerintah kolonial secara tegas memisahkan Islam dari politik, walaupun Islam sebagai ajaran agama dan kegiatan sosial dibiarkan berkembang dengan pengawasan yang ketat. Kecurigaan pemerintah kolonial yang berlebihan terhadap Islam ini membatasi kreatifitas umat, baik dalam pengertian ajaran, pemikiran, maupun penyesuaian diri dengan dinamika dan perubahan yang terjadi dalam masyarakat secara umum. Pun begitu, pemerintah kolonial juga berusaha mengeksploitasi perbedaan yang ada dalam masyarakat yang berhubungan dengan Islam, seperti perbedaan sosio-antropologis antara kelompok santri dan abangan yang menjadi konflik sosial berkepanjangan.

Di tengah kondisi semacam ini, Ahmad Dahlan muncul sebagai salah seorang yang perduli terhadap kondisi yang sedang dihadapi masyarakat pribumi secara umum maupun masyarakat Muslim secara khusus. Sepulang dari dari menunaikan ibadah haji pertama, Ahmad Dahlan mulai dengan membantu ayahnya mengajar para murid yang masih kanak-kanak dan remaja. Dia mengajar pada siang hari sesudah dzuhur, dan malam hari, antara maghrib sampai isya. Sementara itu, sesudah ashar Ahmad Dahlan mengikuti ayahnya yang mengajar agama Islam kepada orang-orang tua dan seringkali menggantikan ayahnya yang sedang berhalangan.

Sepulang dari menunaikan ibadah haji kedua, aktifitas sosial-keagamaan Ahmad Dahlan di dalam masyarakat semakin berkembang. Ia membangun pondok untuk menampung para murid yang ingin belajar ilmu agama Islam secara umum maupun ilmu lain seperti: ilmu falaq, tauhid, dan tafsir. Para murid itu tidak hanya berasal dari wilayah Residensi Yogyakarta, melainkan juga dari daerah lain di Jawa Tengah. Walaupun begitu, pengajaran agama Islam melalui pengajian kelompok bagi anak- anak, remaja, dan orang tua yang telah lama berlangsung terus dilaksanakan. Pengajian rutin mingguan atau bulanan bagi kelompok tertentu seperti pengajian untuk para guru dan pamong praja 
yang berlangsung setiap malam Jum ‘at adalah salah satu pemandangan rutin dalam komplek rumah Ahmad Dahlan.

Dalam pertemuan-pertemuan itu Dahlan berbicara tentang masalah agama Islam maupun masalah umum yang terjadi dalam masyarakat, terutama yang secara langsung berhubungan dengan kestatisan atau keterbelakangan penduduk Muslim pribumi di tengah-tengah masyarakat kolonial. Dalam konteks pergerakan sosial keagamaan, budaya, dan kebangsaan, Dahlan mamanfaatkan kedekatan interaksi personal maupun formal dengan organisasi seperti Budi Utomo, Sarikat Islam, dan Jamiat Khair.

Pada akhirnya, proses belajar mengajar yang dilakukan oleh Ahmad Dahlan diformalkan dengan mendirikan Madrasah Ibtidaiyah Diniyah Islamiyah pada tanggal 1 Desember 1911 M. Saat diresmikan, sekolah itu mempunyai 29 orang siswa dan enam bulan kemudian dilaporkan bahwa terdapat 62 orang siswa yang belajar di sekolah itu. Setahun kemudian, tepatnya pada tanggal 18 Nopember 1912 M, Ahmad Dahlan mendirikan organisasi bernama Muhammadiyah (saat itu bernama Persyarikatan Muhammadiyah). Dengan Madrasah Ibtidaiyah Diniyah Islamiyah dan Muhammadiyah inilah Ahmad dahlan mempertegas upaya pemberdayaan dan pengabdian masyarakat, yaitu melalui pendidikan dan kesadaran akan Islam.

\section{Penutup}

Andai saja pada tahun 1868 tidak lahir seorang bayi bernama Muhammad Darwisy (nama kecil Ahmad Dahlan), Kampung Kauman yang berada di sebelah barat Alun-alun Utara Yogyakarta itu boleh dibilang tak memiliki keistimewaan lain selain sebagai sebuah pemukiman di sekitar Masjid Besar Yogyakarta. Sejarah kemudian mencatat lain, dan Kauman pada akhirnya menjadi sebuah nama besar sebagai kampung kelahiran seorang Pahlawan Kemerdekaan Nasional Indonesia, Kiai Haji Ahmad Dahlan: Sang Penggagas lahirnya Persyarikatan Muhammadiyah pada 8 Dzulhijjah 1330 Hijriyah bertepatan dengan 18 November 1912.

Kebesaran nama Ahmad Dahlan tak kepas dari perhatian dan komitmennya yang tinggi terhadap peta perkembangan sosial-keagamaan masyarakat sekitarnya. Dengan memanfaatkan rumus tantangan-respon Arnold J. Tonybe bahwa tingkat keberlangsungan dan derajat kekokohan individu di masa 
depan akan selalu berbanding-lurus dengan tingkat kemauan dan derajat komitmen individu hari ini untuk merespon tantangan terkininya secara cepat dan tepat, maka dapatlah dipastikan bahwa KH. Ahmad Dahlan adalah sosok yang mampu merespon tantangan terkininya secara cepat dan tepat. Tentu saja perjalanannya tidak semudah membalikkan telapak tangan, karena kesulitan memanglah salah satu sifat niscaya dari kebenaran. Jika tidak demikian, maka harga proses konstan di jalan menuju kebenaran dan harga ketahanan moral dalam penyampaian kebenaran akan menjadi nol besar. "If we don't change, we don't grow; If we don't grow, we are not really living; Growth demands a temporary surrender of security". 


\section{Daftar Pustaka}

Ali, A. Mukti., The Muhammadiyah Movement: Allah SWT Bibliographical Introcution", Tesis Master pada Institute of Islamic Studies. Mc Gill Univercity, Montreal, 1957.

Hadjid, Haiban. Pelajaran KH. Ahmad Dahlan: 7 Falsafah Ajaran dan 17 Kelompok Ayat Al-Qur'an, Yogyakarta: LPI PPM, 2008.

Ihsan, Hamdani dan Fuad Ihsan. Filsafat Pendidikan Islam, Bandung: Pustaka Setia, 2001

Mulkhan, Abdul Munir. Masalah-Masalah Teologi dan Fiqih dalam Tarjih Muhammadiyah, Yogyakarta: Roykhan, 2005.

Nata, Abuddin. Tokoh-tokoh Pembaruan Islam di Indonesia, Jakarta: Raja Grafindo Persada, 2005.

Nizar, Samsul. Filsafat Pendidikan Islam: Pendidikan Historis Teoritis, Jakarta: penerbit Ciputat Press, 2002.

Suwarno, Margono Poespo. Gerakan Islam Muhammadiyah, Yogyakarta: Persatuan Baru, 2005.

Wirjosukarto, Amir Hamzah. Pembaharuan Pendidikan dan Pengajaran Islam, Jember: Mutiara Offset, 1985

http://www.tokohindonesia.com/ensiklopedi/a/ahmad-dahlan/index.html. 